\title{
Simultaneous Optimization of Rigidity and Strength of Super Invar Cast Steel using by Martensitic Reversion
}

\author{
Naoki SAKAGUCHI ${ }^{1,2)^{*}}$, Haruyasu $\mathrm{OHNO}^{2)}$ and Nobuo NAKAdA ${ }^{1)}$ \\ 1) Shinhoukoku Steel Corporation \\ 2) Department of Materials Science and Engineering, Tokyo Institute of Technology
}

Abstract: Super invar cast steel, Fe-32\%Ni-5\%Co by mass \%, with excellent low coefficient of thermal expansion has disadvantages in the both of Young's modulus and strength, because of coarse columnar solidification structure having $<100>$ texture. To simultaneously overcome these disadvantages, the variations of microstructure and mechanical properties through the novel heat treatment referred to as cryo-annealing, which is consisting of subzero treatment and subsequent annealing, were investigated in a super invar cast steel. The cryo-annealing promoted fcc-bcc martensitic transformation and then bcc-fcc martensitic reversion. The bidirectional martensitic transformations led to the formation of duplex austenitic structure consisting of untransformed and reversed austenite with a coarse-grained structure similar to solidification structure. Furthermore, it is found that the austenitic structure was varied depending on the annealing temperature of the cryo-annealing; reversed austenite was remained at lower annealing temperature, while it recrystallized to fine-grained structure as increasing annealing temperature. The high-density dislocations in reversed austenite and the randomized orientation of recrystallized austenite contributed to the development of strength and Young's modulus, respectively. Therefore, the simultaneous development of rigidity and strength is not achieved by single cryo-annealing, but can be achieved by two-cycle cryo-annealing. Increasing the first annealing temperature and lowering the second annealing temperature in the two-cycle cryo-annealing are appropriate to randomize crystal orientation through austenite recrystallization and to make volume fraction of reversed austenite higher, respectively. As a result, Young's modulus and $0.2 \%$ strength were simultaneously optimized.

Keywords: super invar; cast steel; austenite; reversion; recrystallization.

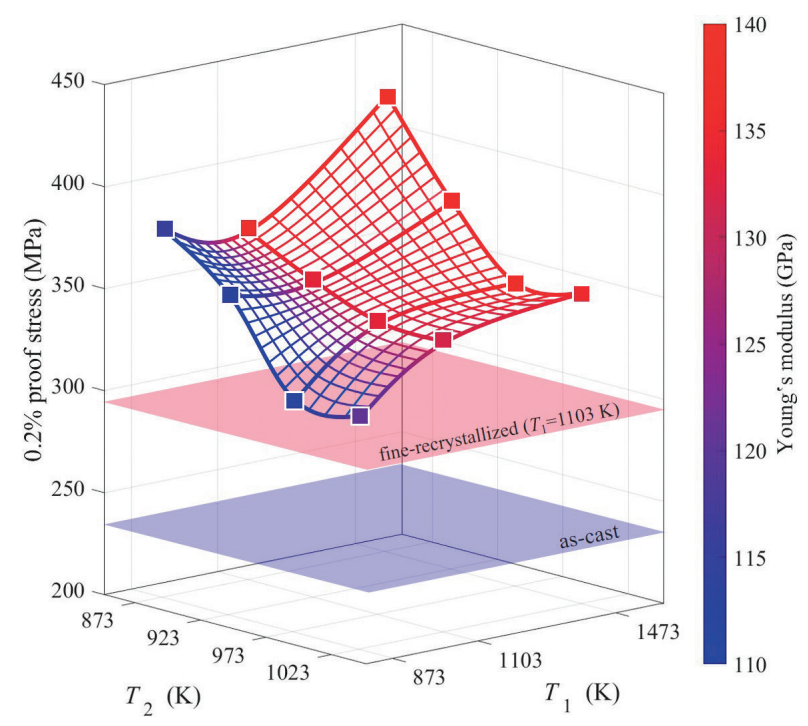




\title{
マルテンサイト逆変態を活用したスーパーインバー鋳鋼の 剛性と強度の同時最適化
}

\author{
坂口 直輝 ${ }^{1,2)} *$ 大野 晴康 $^{2)} \cdot$ 中田 伸生 ${ }^{1)}$
}

Simultaneous Optimization of Rigidity and Strength of Super Invar Cast Steel using by Martensitic Reversion

Naoki SAKAguchi, Haruyasu OhNo and Nobuo NAKAdA

\section{1. 緒言}

$\mathrm{Fe}-32 \% \mathrm{Ni}-5 \% \mathrm{Co}(\mathrm{mass} \%)$ の組成を有するスーパーイン バー合金は，その極めて低い熱膨張特性から高い寸法精度 が要求される精密部材に使用されている。近年，スーパー インバー合金が使用される構造体は形状の複雑化や大型化 が進んで打り，ニアーネットシェイプである鋳鋼品の使用 が不可欠になっている。しかしながら，スーパーインバー 鋳鋼では $<100>$ 集合組織が発達する粗大な柱状晶組織が形 成するためヤング率が低く ${ }^{1)}$ ，この低い剛性が大型構造体 としてのひとつの課題となっている。著者ら ${ }^{2)}$ は, 塑性加 工を用いずにスーパーインバー鋳鋼の低剛性を改善するこ とを目的に，サブゼロ処理と焼鈍処理を組み合わせたクラ イオアニール処理を提案した。

スーパーインバー鋳鋼は，その組成からマルテンサイト 変態開始温度 : $M_{\mathrm{s}}$ 点が比較的高く, サブゼロ処理によって 多量のマルテンサイトが生じる（fcc-bcc マルテンサイト変 態)。そして，その後の焼鈍処理では，サブゼロ処理で生成 したマルテンサイトがオーステナイトへとマルテンサイト 変態によって逆変態する (bcc-fcc マルテンサイト逆変態)。 そのため，クライオアニール処理によって生成するオース テナイトは二度のマルテンサイト変態によって高密度の転 位を含有しており，この高密度転位によって再結晶するこ とが知られている ${ }^{3)}$ 。すなわち，スーパーインバー鋳鋼で は，熱処理のみでオーステナイトを再結晶させることが可 能であり，これによって集合組織の解消とヤング率の改善 を達成した。

その一方で，スーパーインバー鋳鋼は炭素繊維強化プラ スチックの金型にも利用されており，ヤング率の改善に加 えて, 強度の上昇も求められている。インバー合金の高強 度化について, 塑性加工による転位強化 ${ }^{4,5)}$ や粒子分散強 化 ${ }^{6,7)}$ に関する研究が報告されている。しかしながら, 塑性 加工は鋳鋼品には適用できず，粒子分散強化を可能にする
合金元素の添加は熱膨張特性を悪化させてしまう ${ }^{6-8)}$ 。こ れに対して，上述したクライオアニール処理はスーパーイ ンバー合金の基本組成を変えず, 塑性加工を必要とせずに ミクロ組織の変化をもたらすため，これに起因したオース テナイトの高強度化が期待できる。とくに，二度のマルテ ンサイト変態によって形成する逆変態オーステナイト中の 高密度な転位は転位強化として，その一方で，顕著なオ一 ステナイト再結晶は結晶粒微細化強化をもたらすと考えら れる。

そこで, 本研究では, クライオアニール処理に伴ったヤ ング率と強度の変化を調査し, これらの変化挙動と組織の 関係を考察した。そして，スーパーインバー鋳鋼の剛性と 強度を同時に改善する最適な熱処理条件を検討した。

\section{2. 実験方法}

本研究では, Table 1 に示す化学組成を有するスーパー インバー合金を供試材として用いた。試料は大気高周波溶 解炉を用いて溶解し, Fig.1に示した $400 \times 400 \times 150 \mathrm{~mm}^{3}$ の砂型に鋳込むことで鋼塊を作製した。なお，スラブ中に 引け巣などの欠陷が生じることを防ぐため， $\phi 240 \mathrm{~mm} \times$ $240 \mathrm{~mm}$ 押湯をスラブ中心部に設置した (Fig.1 (a))。得ら れた鋼塊より $\phi 6.0 \mathrm{~mm} \times 25 \mathrm{~mm}$ の円柱試験片を採取し, NETZECH 製DIL-402C 熱膨張測定機を用いて各変態点を 測定したところ，冷却によって生じる fcc-bcc マルテンサ イト変態の開始温度 $: M_{\mathrm{s}}$ 点は $224 \mathrm{~K}$ ，その後の焼鈍によっ て生じる bcc-fec マルテンサイト逆変態の開始温度 : $A_{\mathrm{s}}$ 点と終了温度： $A_{\mathrm{f}}$ 点はそれぞれ $741 \mathrm{~K}$ と $860 \mathrm{~K}$ であった。

Table 1. Chemical composition of a super invar cast steel used in this study (mass\%).

\begin{tabular}{c|c|c|c|c|c|c|c|c}
\hline & $\mathrm{C}$ & $\mathrm{Si}$ & $\mathrm{Mn}$ & $\mathrm{P}$ & $\mathrm{S}$ & $\mathrm{Ni}$ & $\mathrm{Co}$ & $\mathrm{Fe}$ \\
\hline$\square 400 \times 150^{\mathrm{T}}$ & 0.017 & 0.10 & 0.23 & 0.005 & 0.003 & 31.88 & 5.14 & Bal. \\
\hline
\end{tabular}


Fig.1（b）に示すように, 組織観察，引張試験，ヤング率測 定の試験片を鋼塊中心部の幅 $25 \mathrm{~mm}$ の領域から採取した。 なお, 引張試験片は平行部体積 $2.0 \times 10 \times 25 \mathrm{~mm}^{3}$ の板状引 張試験片（Fig.1 (c)) とし，板厚面に結晶粒が 5 個以上存在 することを確認した。切り出した試験片は，液体窒素に浸 漬させることにより $77 \mathrm{~K} に て 3.6 \mathrm{ks}$ のサブゼロ処理を行っ た。その後，873 K〜1473 Kの種々の温度にて $7.2 \mathrm{ks}$ 保持す る焼鈍処理を施した後，水冷した。この一連のサブゼロ処 理およびその後の焼鈍処理をクライオアニール処理と呼称 する。そして，後述するように，一部の試料に対して 2 回の クライオアニール処理を行うダブルクライオアニール処 理を施した（Fig.2）。1回目および2回目のクライオアニー 儿処理における焼鈍処理温度は，それぞれ $T_{1}=873 \mathrm{~K} \sim$ $1473 \mathrm{~K}, T_{2}=873 \mathrm{~K} \sim 1023 \mathrm{~K}$ とし。組織観察には光学顕
微鏡（OLYMPUS 製DP20）を使用した。光顕用試料はFig.1 に示す切断面に平行な面を, エメリー紙\#1200までの湿式 研磨後，ダイヤモンド遊離砥粒を用いたバフ研磨を行っ た。鏡面まで仕上げた観察面に対してマーブル夜 $\left(\mathrm{Cu}_{2} \mathrm{SO}_{4}\right.$. $\left.5 \mathrm{H}_{2} \mathrm{O}: \mathrm{HCl}: \mathrm{H}_{2} \mathrm{O}=10 \mathrm{~g}: 50 \mathrm{ml}: 50 \mathrm{ml}\right)$ にて室温で腐食し た試料を観察した。得られた光顕組織から，オーステナイ トの平均結晶粒径はJIS G 0551 に準じた求積法を適用する ことで測定し，マルテンサイトの面積率は画像解析によっ て評価した。引張試験はインストロン型万能試験機（島津 製作所製 $\mathrm{AG}-\mathrm{X})$ を使用し，初期ひずみ速度 $1.7 \times 10^{-3} \mathrm{~s}^{-1}$ にて実施した。ヤング率測定は $7.0 \times 16 \times 125 \mathrm{~mm}^{3}$ の試験 片を用いて小野測器製オシロスコープにて共振周波数を測 定することで評価した。熱膨張測定は $\phi 6.0 \mathrm{~mm} \times 25 \mathrm{~mm}$ の円柱試験片を用いて, 熱膨張測定機にて 273 K〜 343 Kの

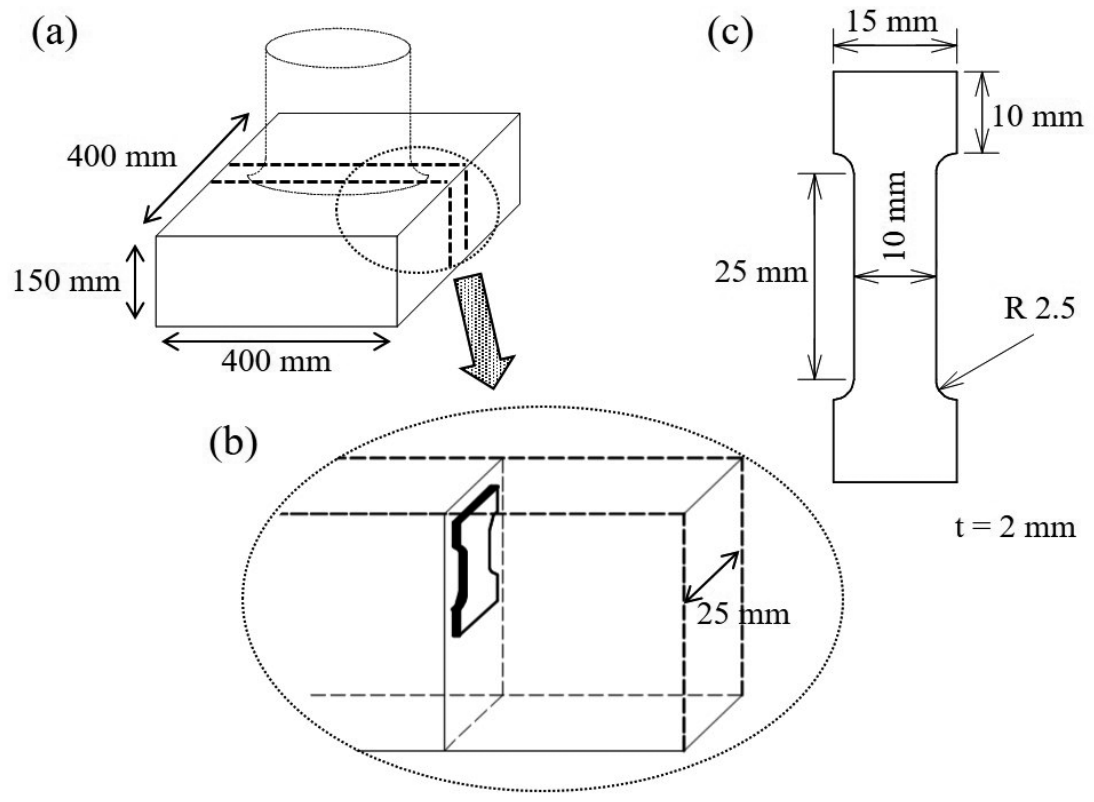

Fig. 1. Schematic illustration showing the position and the shape of tensile test piece cut from a cast material.

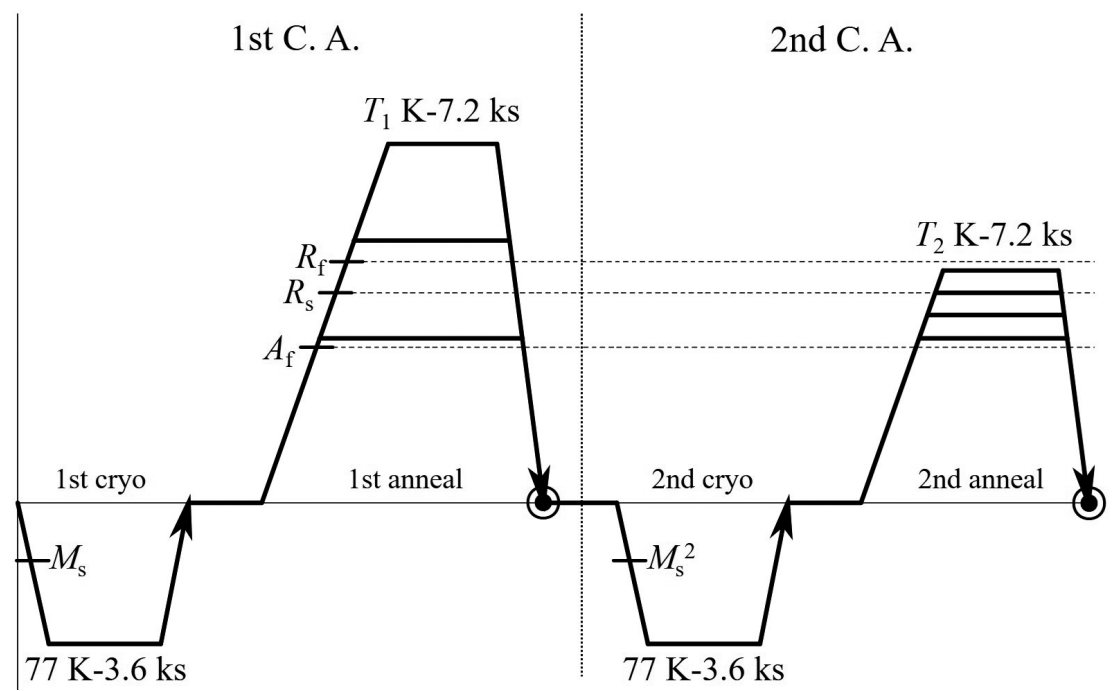

Fig. 2. Heat treatment route of cryo-annealing process (C. A.) applied for super invar cast steel. 
熱膨張を測定し， $291 \mathrm{~K} \sim 301 \mathrm{~K}$ の平均熱膨張係数で評価し た。

\section{3. 結果と考察}

\section{$3 \cdot 1$ クライオアニール処理に伴うスーパーインバー鋳鋼の組 織と力学特性変化}

$3 \cdot 1 \cdot 1$ 逆変態後のオーステナイト組織に及ぼす焼鈍温 度の影響

Fig.3 は，鋳造ままの as-cast材ならびにサブゼロ処理後の subzero材, そして, 種々の温度で焼鈍した試料の光顕組織 を示す。as-cast材 (a) は粗大な凝固組織を有し，黒矢印で 示すように観察視野内に結晶粒界はわずかにしか存在し ない。そして, subzero材 (b) では, 針状のレンズマルテン サイト $\left(\alpha^{\prime}\right)$ が $87 \%$ の体積率で生成しており，未変態オー ステナイト $\left(\gamma_{\text {unt }}\right)$ との複相組織を呈していた。このとき, レンズマルテンサイトは Ni濃度の低いデンドライトに優 先的に生成するため，その分布はオーステナイト組織とは 独立して分布していた ${ }^{2)}$ 。この複相組織を $A_{\mathrm{f}}$ 点 $(860 \mathrm{~K})$ 以 上の温度で焼鈍することにより，レンズマルテンサイトは 再びオーステナイトへと逆変態し，オーステナイト単相と なったが，その組織は焼鈍温度によって大きく変化した。 黒矢印でオーステナイト粒界を示すように，873 K焼鈍材 (c) ではas-cast材 (a) と同様の粗大オーステナイト組織が 観察されたが，その内部にはレンズマルテンサイトに似た 針状の下部組織 (ゴースト $)^{9-11)}$ が確認できる。これらの組 織的特徵は, 非熱弾性型マルテンサイト変態拉よびマルテ
ンサイト逆変態によって結晶方位の可逆変化が生じる結 果, 未変態オーステナイトと同一結晶方位を有しつつ高密 度の転位を含有した逆変態オーステナイトが形成すること を示している。すなわち， $A_{\mathrm{f}}$ 点直上では，逆変態オーステ ナイト $\left(\gamma_{\mathrm{rev}}\right)$ と未変態オーステナイトの混合組織で形成さ れた粗大オーステナイト組織が形成されることがわかる。 その一方で，973 K焼鈍材 (d) では，白矢印で示すように， 未変態オーステナイトと逆変態オーステナイトの転位密度 差に起因したオーステナイト再結晶が生じることが確認さ れた ${ }^{3)}$ 。その結果，焼鈍温度がさらに高い $1103 \mathrm{~K}$ 焼鈍材 (e) において, 逆変態オーステナイトに起因したゴーストは完 全に消失し，微細な再結晶オーステナイト $\left(\gamma_{\mathrm{rex}}\right)$ 組織が試 料全面で観察された。そして，さらに焼鈍温度が上昇する ことで, 粒成長によって等軸なオーステナイト組織が形成 した (f)。以上の組織観察より，本供試材におけるオース テナイトの再結晶開始温度 $R_{\mathrm{s}}$ および終了温度 $R_{\mathrm{f}}$ は，それそ れ $950 \mathrm{~K}$ と $1050 \mathrm{~K}$ 程度であることが明らかとなった。以降 では，873 K，1103 K，1473 K焼鈍材を逆変態材，微細再結 晶材, 粗大再結晶材と呼称し, これらを中心にその諸特性 を説明する。

$3 \cdot 1 \cdot 2$ 材料特性に及ぼすオーステナイト組織の影響

Fig.4は, as-cast材, subzero材に加えて, 逆変態材, 微細 再結晶材, 粗大再結晶材の公称応力ーひずみ曲線を示す。 レンズマルテンサイトを含有する subzero材は, オーステ ナイト単相である他の試料と比較して, 極めて高い強度と 低い延性を特徴とする。しかしながら, オーステナイト単 相組織を有する他の 4 試料間でも, その応力ーひずみ曲線

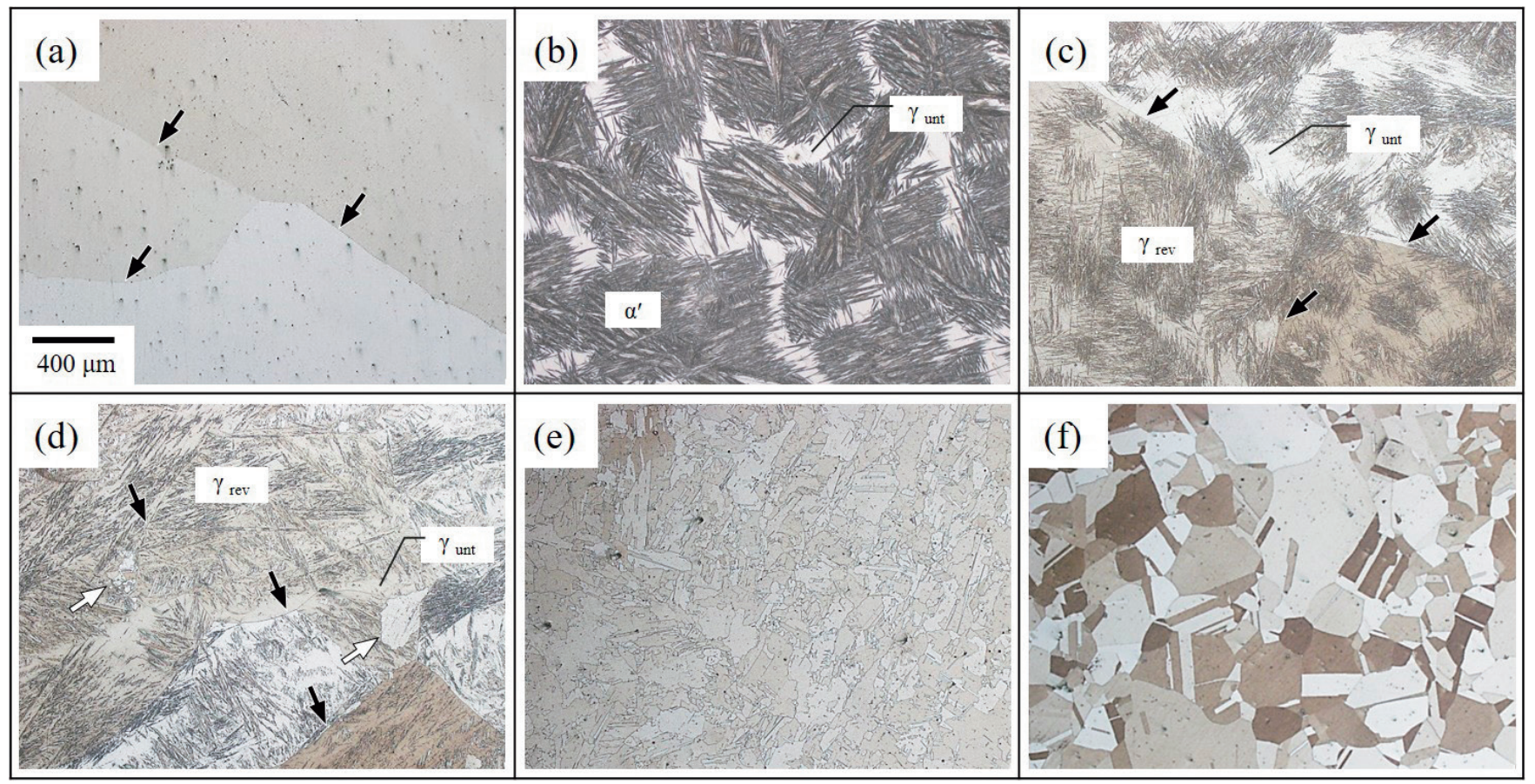

Fig. 3. Optical micrographs showing microstructural evolution during cryo-annealing process. (a) as-cast, (b) subzero treated and cryoannealed materials, which were annealed at (c) $873 \mathrm{~K}$, (d) $973 \mathrm{~K}$, (e) $1103 \mathrm{~K}$ and (f) $1473 \mathrm{~K}$. (Online version in color.) 
は大きく異なる。逆変態材は500 MPaを超える非常に高い 引張強度を有して打り, 逆変態オーステナイトの形成が オーステナイト鋼の高強度化に有効であることが理解でき る。著者らのひとりは, このような逆変態材の高強度化が 逆変態オーステナイト中の高い転位密度に起因すること を報告し, 逆変態オーステナイト体積率とその組織連結性

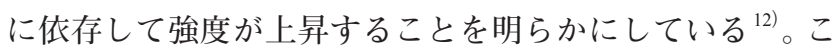
れに対して, 微細再結晶材打よび粗大再結晶材は, 不均一 変形時に大きな強度低下を示しており, 優れた絞りを有す ることが示唆される。ただし, どちらの再結晶材も, as-cast 材に比べて十分に高い強度を示しており, 再結晶による結 晶粒微細化強化が有意に働くことが示唆される。

引張試験によって評価した (c) $0.2 \%$ 耐力に加えて，(a) 熱膨張率と (b) ヤング率に及ぼすクライオアニール処理に おける焼鈍温度の影響を Fig. 5 にまとめる。なお，比較とし て, as-cast材と subzero材のデータも併記しており, 組織変 化との対応を理解するため $A_{\mathrm{f}}, R_{\mathrm{s}}, R_{\mathrm{f}}$ 点を破線で示してい る。まず, 熱膨張率に着目すると (a), bcc 相であるレンズ マルテンサイトを含む subzero材以外の全ての試料は $5.0 \times$ $10^{-7} \mathrm{~K}^{-1}$ 以下の極めて低い熱膨張率を示しており，オース テナイト単相であれば，スーパーインバー合金の特徴であ る低熱膨張特性が維持されることがわかる。ヤング率 $(\mathrm{b})$ は $A_{\mathrm{f}}$ 点直上では低くいものの, $R_{\mathrm{s}}$ から $R_{\mathrm{f}}$ 点の間で急激に改 善され，1050 K以降ではほぼ一定となった。これは，再結 晶によって凝固組織に発達した $<100>$ 集合組織がランダム

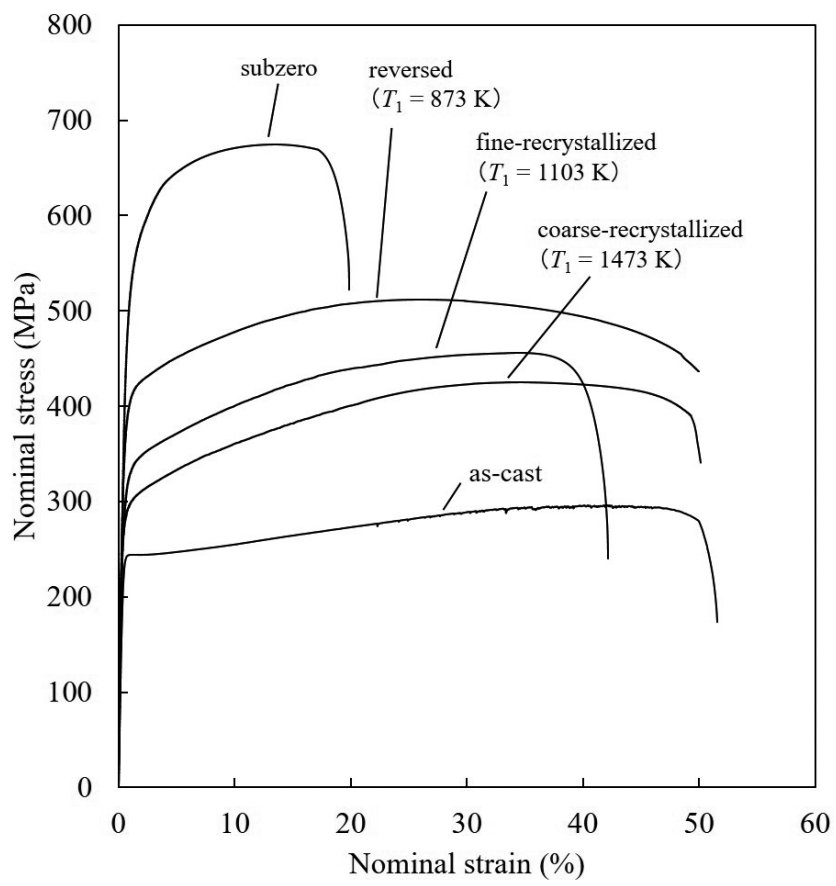

Fig. 4. Nominal strain-stress curve of as-cast, subzero and cryo-annelaed materials. Cryo-annealed materials were annealed at $T_{1}=873 \mathrm{~K}, 1103 \mathrm{~K}$ and $1473 \mathrm{~K}$, reversed, fine-recrystallized and coarse-recrystallized materials, respectively.
化されたことに対応する ${ }^{2)}$ 。このヤング率変化とは対照的 に, $0.2 \%$ 耐力は $950 \mathrm{~K}$ まで高い值を保った後, 焼鈍温度の 上昇に伴って単調に低下寸る。この強度低下は, 再結晶に よって微細粒組織が形成されるものの, その微細化強化量 は逆変態オーステナイト中の転位強化量に比べて小さいこ とを示しており, 逆変態オーステナイトの消失ならびに再 結晶オーステナイトの粒成長によって強度が連続的に低下 したものと理解できる。

これらの結果から, 逆変態オーステナイトを主構成組織 とする高強度な逆変態材は集合組織の継承により依然と してヤング率が低いのに対して，結晶方位のランダム化に よってヤング率が改善した再結晶材では, 十分な強度上昇 を達成できないことが明らかとなった。すなわち, 単純な クライオアニール処理ではヤング率と強度の同時改善は達 成できないと結論づけられる。そこで, 以降では，両特性 の同時改善を目指し, 2 度のクライオアニール処理を実施 する有効性を検証した。

\section{$3 \cdot 2$ ダブルクライオアニール処理に伴うスーパーインバー鋳 鋼の組織と力学特性変化 \\ $3 \cdot 2 \cdot 1$ マルテンサイト体積率に及ぼすオーステナイト 組織の影響}

Fig.6は，クライオアニール処理によってオーステナイ 卜単相となった (a) 逆変態材 $\left(T_{1}=873 \mathrm{~K}\right),(\mathrm{b})$ 微細再結 晶材 $\left(T_{1}=1103 \mathrm{~K}\right)$ 打よび $(\mathrm{c})$ 粗大再結晶材 $\left(T_{1}=1473 \mathrm{~K}\right)$

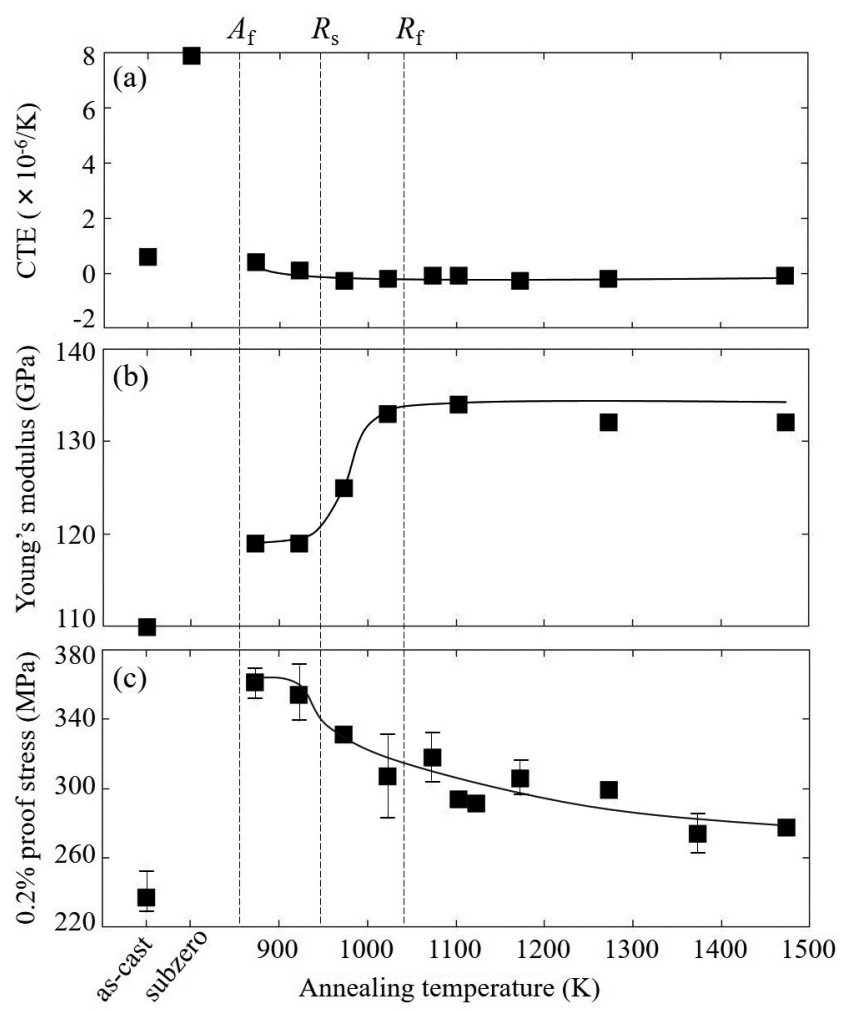

Fig. 5. Changes in (a) coefficient of thermal expansion (CTE), (b) Young's modulus and (c) $0.2 \%$ proof stress of super invar cast steel as a function of annealing temperature of cryo-annealing process. 
に対して, 再度サブゼロ処理を実施した後の光顕組織を示 し，これによって生成したマルテンサイトの体積率 $V_{\mathrm{M}} も$ 同時に表示している。 $V_{\mathrm{M}}$ は広範囲での組織観察により測 定しており，X線回析による相同定の結果とほぼ一致する ことを確認した。鋳造ままのas-cast材をサブゼロ処理に供 した場合, $\mathrm{Ni}$ 濃度の低いデンドライト部に優先してレンズ マルテンサイトが生成し， $V_{\mathrm{M}}=87 \%$ となった（前揭Fig.3 (b))。これと同様に逆変態材をサブゼロ処理に供した場 合 (a)，デンドライト部に沿って優先的にレンズマルテン サイトが再び生成するが, $V_{\mathrm{M}}$ は $47 \%$ と小さい。そして, 逆 変態材に新たに生成したマルテンサイトの周囲には1回 目のクライオアニール処理で生じた逆変態オーステナイ ト $\left(\gamma_{\text {rev1 }}\right)$ が多数観察された。Krauss ${ }^{9)}$ ならびにImai $~^{13)}$ は, $\mathrm{Fe}-(30.5-33.5) \% \mathrm{Ni}-0.005 \% \mathrm{C}$ 合金打よび $\mathrm{Fe}-(27.6-30.7)$ $\% \mathrm{Ni}$ 合金を用いて，マルテンサイト変態とその後のマルテ ンサイト逆変態を複数回行った際の変態挙動を調査した。 その結果, 変態回数が増える度に $M_{\mathrm{s}}$ 点が連続して低下寸 るとともに，マルテンサイト体積率が減少することを報告 し，マルテンサイト逆変態によって生成したオーステナイ トが高い熱的安定性を有することを明らかにしている。す なわち, 逆変態材ではデンドライト部に逆変態オーステナ イトが分布するため, 2 度目のマルテンサイト変態が著し く抑制されたと理解できる。その一方で, 微細ならびに粗 大再結晶材では, マルテンサイトがデンドライト部に優先 的に分布する様子を明確に確認することができなかった $(\mathrm{b}, \mathrm{c})$ 。ただし, 微細再結晶材 (b) と比較して, 粗大再結晶 材 (c) では, 生成するマルテンサイト組織が粗大であると ともに $V_{\mathrm{M}}$ もきいことから, 再結晶後のオーステナイト 粒径が，その後のマルテンサイト変態挙動に影響を及ぼす ことが示唆される。そこで, Fig.6に示した3つの試料にascast材を加え，サブゼロ処理における (a) $M_{\mathrm{s}}$ 点ならび (b) V Mをオーステナイト粒径で整理した結果を Fig.7に示す。 前述したオーステナイト安定化効果により, 逆変態オース テナイトが主体となる逆変態材は, as-cast材に比べて $V_{\mathrm{M}}$ のみならず $M_{\mathrm{s}}$ 点も $50 \mathrm{~K}$ ほど低い值を示した。その一方で, 逆変態オーステナイトを含まない微細再結晶材, 粗大再結 晶材およびas-cast材を比較すると，オーステナイト粒径の 微細化に伴って $M_{\mathrm{s}}$ 点が連続して低下寸ることがわかる。 Umemoto and Owen ${ }^{14)}$ は, 平均結晶粒径を $20 \sim 450 \mu \mathrm{m}$ に変 化させた $\mathrm{Fe}-31 \% \mathrm{Ni}-0.28 \% \mathrm{C}$ 合金を用いてオーステナイト 結晶粒径と $M_{\mathrm{s}}$ 点の関係を調査している。そして，オーステ ナイト粒径の微細化によって $M_{\mathrm{s}}$ 点が連続的に低下し，とく に $100 \mu \mathrm{m}$ 以下の粒径では, $M_{\mathrm{s}}$ 点低下が顕著になることを 報告している。さらに, Tsuzaki and Makiは，この結晶粒微 細化に起因したオーステナイトの安定化について, 結晶粒 界がレンズマルテンサイトの成長の障害になるためと指摘 している ${ }^{15)}$ 。このことは, 微細再結晶材 (Fig.6 (b)) では微 細なレンズマルテンサイトが生成するのに対して, 粗大再 結晶材 (Fig.6 (c)) や as-cast材 (Fig.3 (b)) に生成するレン ズマルテンサイト組織が粗大なことに対応すると考えられ

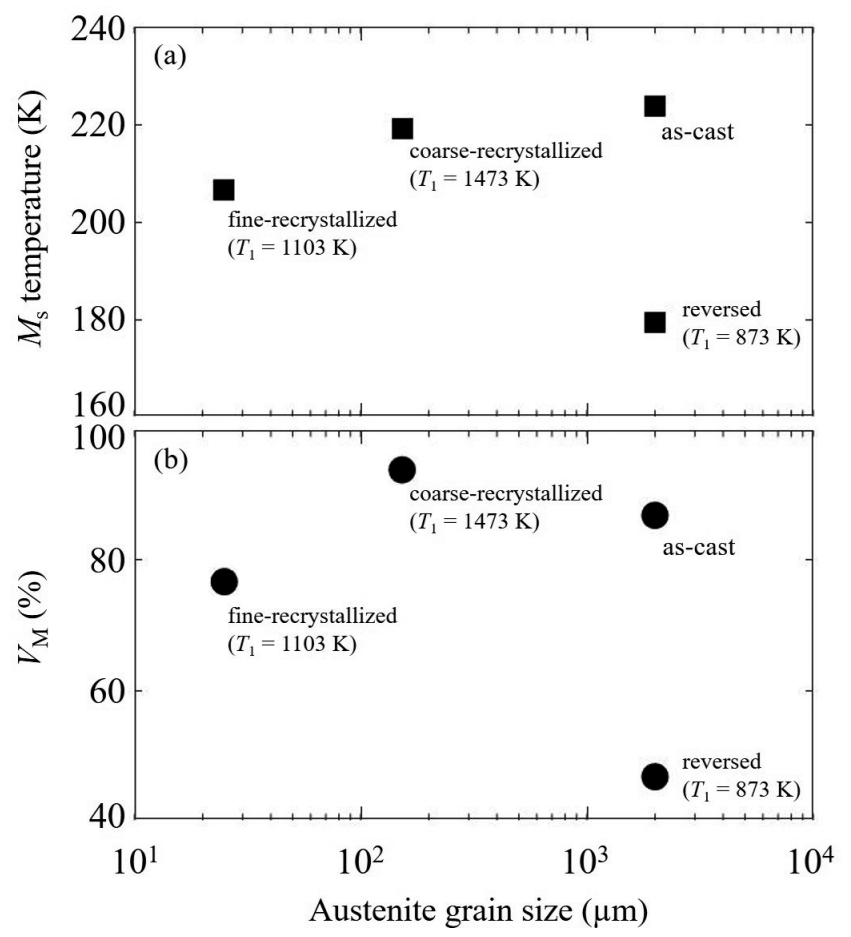

Fig. 7. Effect of austenite grain size on (a) martesite start tempertaure $\left(M_{\mathrm{s}}\right)$ and (b) volume fraction of martesite $\left(V_{\mathrm{M}}\right)$.
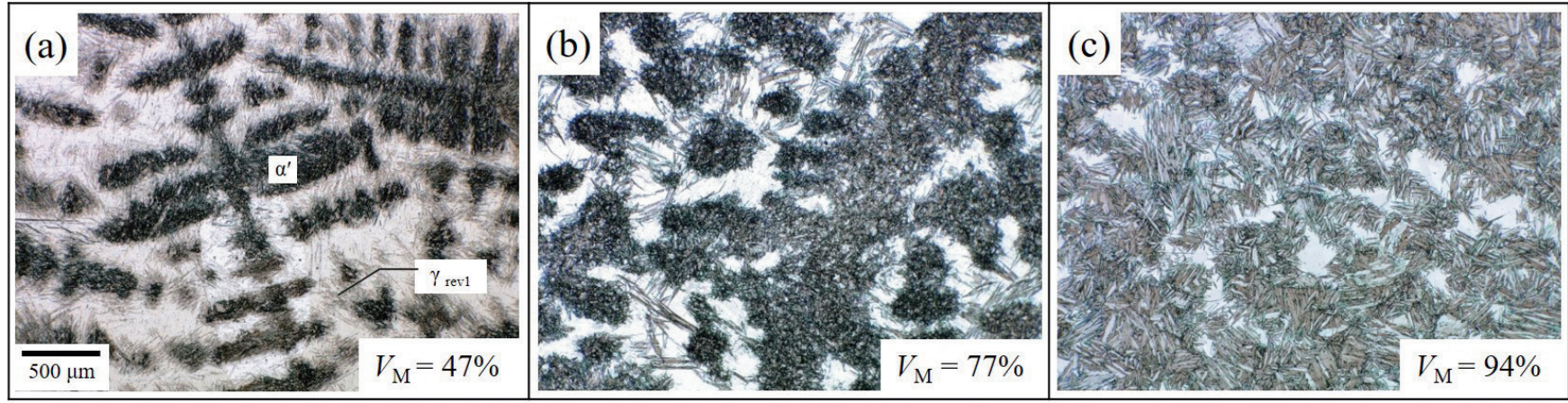

Fig. 6. Optical microstructure of (a) reversed $\left(T_{1}=873 \mathrm{~K}\right)$, (b) fine-recrystallized $\left(T_{1}=1103 \mathrm{~K}\right)$ and (c) coarse-recrystallized $\left(T_{1}=1473\right.$ $\mathrm{K})$ materials after subzero treatment at $77 \mathrm{~K}$ for $3.6 \mathrm{ks}$. (Online version in color.) 
る。この $M_{\mathrm{s}}$ 点のオーステナイト粒径依存性に対応し，オー ステナイト粒径の微細化に伴って $V_{\mathrm{M}}$ も減少する傾向が確 認できる。しかしながら, 粗大再結晶材の $V_{\mathrm{M}}$ は as-cast材の それよりも約 10\%大きく，特異な挙動を示した。一般的に オーステナイト粒界はマルテンサイトの優先核生成サイト になると考えられている。そのため, バースト現象と呼ば れる変態初期のレンズマルテンサイト成長がオーステナイ 卜粒界で阻害され, $M_{\mathrm{s}}$ 点が低下しても, 十分に変態が進行 した段階ではオーステナイト粒径の微細化に起因した核生 成密度の増大によって $V_{\mathrm{M}}$ が結果的に増加したと考えられ る。

\section{$3 \cdot 2 \cdot 2$ 力学特性に及ぼすダブルクライオアニール処理 条件の影響}

Fig.8は逆変態材, 微細再結晶材打よび粗大再結晶材に対 して, 2 度目のクライオアニール処理を適用し，オーステ ナイト単相とした試料の $0.2 \%$ 耐力とヤング率を 1 回目な らびに2 回目のクライオアニール処理に打ける焼鈍温度 $T_{1}$ と $T_{2}$ で整理したものであり, 比較として as-cast材および微 細再結晶材 $\left(T_{1}=1103 \mathrm{~K}\right)$ のデータについても併記した。 なお, ダブルクライオアニール処理後, いずれの試料も 1.0 $\times 10^{-7} \mathrm{~K}^{-1} \sim 8.0 \times 10^{-7} \mathrm{~K}^{-1}$ と低い熱膨張率を維持するこ とを確認した。カラーコンターで示したヤング率は, $T_{2} に$ 対して鈍感である一方, $T_{1}$ に対しては明瞭な温度依存性を 示し， $T_{1}$ の上昇に伴って大きく増加した。これとは対照的 に, $0.2 \%$ 耐力は $T_{2}$ 温度に大きく影響を受けており, $A_{\mathrm{f}}$ 点直

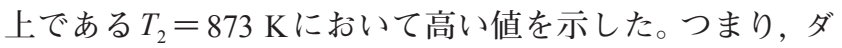
ブルクライオアニール処理において, $T_{1}$ を高く, かつ, $T_{2}$ を $A_{\mathrm{f}}$ 点直上の低温とすることで，スーパーインバー鋳鋼の $0.2 \%$ 耐力とヤング率の両特性を同時に高めることが可能 であると結論づけることができる。

ダブルクライオアニール処理後の $0.2 \%$ 耐力が $T_{2}$ に強く 影響されることが明らかとなったが， $T_{2}$ を $873 \mathrm{~K} に$ 固定し た場合， $0.2 \%$ 耐力は $T_{1}$ に依存して単調に変化しないこと に気付く。Nagpaul and West ${ }^{16)}$ ならびにNakadaら ${ }^{12)}$ は, Fe$25.7 \% \mathrm{Ni}-0.4 \% \mathrm{C}$ 合金打よび $\mathrm{Fe}-28 \% \mathrm{Ni}$ 合金を用いて, クラ イオアニール処理後の未変態オーステナイトと逆恋態オー ステナイトから成る複合組織オーステナイト鋼の力学特性 を引張試験によって評価している。この際, サブゼロ処理 温度を変化させることで逆変態オーステナイトの体積率を 変化させて打り，いずれの報告においても，複合組織オー ステナイト鋼の $0.2 \%$ 耐力が逆変態オーステナイト体積率 に強く支配されることを報告している。そこで，ダブルク ライオアニール処理後の各試料ならびに逆変態材, 微細 再結晶材打よび粗大再結晶材における $0.2 \%$ 而力と逆変態 オーステナイト体積率 $V_{\gamma \text { rev }}$ の関係をFig.9にまとめる。な お，逆変態材を $T_{2}=873 \mathrm{~K}$ のクライオアニール処理に供し た試料 (図中のロ, $873 \mathrm{~K}+873 \mathrm{~K}$ ) では, 2 回目のクライオ アニール処理で生成した逆変態オーステナイト $\left(\gamma_{\mathrm{rev} 2}\right)$ と

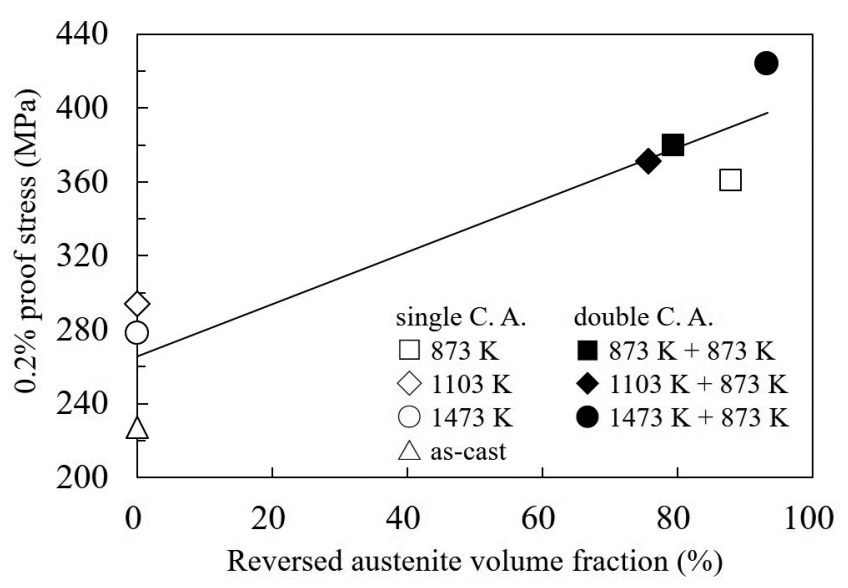

Fig. 9. Relation between $0.2 \%$ proof stress and volume fraction of reversed austenite in super invar cast steel subjected to single and double cryo-annealing process.

は別に, 1 回目のクライオアニールで生成したもの $\left(\gamma_{\mathrm{rev} 1}\right)$ が混在することに留意しなければならない (Fig.6 (a))。し かしながら, Krauss ら ${ }^{9,17)}$ ならびにAlaei ら ${ }^{18)}$ の報告によれ ば, マルテンサイト変態ならびに逆変態が生じるクライオ アニール処理を複数回繰り返した場合, マルテンサイト逆 変態によるオーステナイトの強化は 1 回目の熱処理が顕著 であり，それ以降の熱処理サイクルはあまり効果的でない ことが報告されている。これは, 熱処理過程における転位 の回復を無視すれば, $\gamma_{\mathrm{rev} 1}$ と $\gamma_{\mathrm{rev} 2}$ の強度が同程度であること を示唆している。そのため, 逆変態オーステナイト体積率 $V_{\gamma_{\text {rev }}}$ は, $\gamma_{\text {rev1 }}$ と $\gamma_{\mathrm{rev} 2}$ の体積率を合計した值で評価した。各試 料の強度と $V_{\gamma \text { rev }}$ の間には, 明膫な線形関係を見出すことが でき, ダブルクライオアニール処理後の強度は逆変態オー ステナイト体積率に支配されることが明らかとなった。

以上の結果より, スーパーインバー鋳鋼の剛性改善と高 強度化を達成する最適熱处理プロセスを Fig.10に模式的に 示す。まず，1回目のクライオアニール処理ではマルテン サイト逆変態によって誘起されるオーステナイト再結晶を 発現させることで, 結晶方位のランダム化させ剛性改善を 困る。ここで, 焼鈍温度を意罒的に高くすることで再結晶 オーステナイトを粗大化させ，その後のサブゼロ処理にお けるマルテンサイト変態の促進を図ることが重要となる。 そして, 2度目のクライオアニール処理にて転位強化され た高強度な逆変態オーステナイトを多量に生成させる。以 上のようなダブルクライオアニール処理により, スーパー インバー鋳鋼の剛性と強度は，それぞれ最大で $30 \%$ と $90 \%$ 程度向上することが明らかとなった。

\section{4. 結言}

スーパーインバー鋳鋼に打けるヤング率と強度の同時改 善を目指して，サブゼロ处理とその後の焼鈍処理 (クライ オアニール処理）を実施し，これに伴う組織と力学特性の 


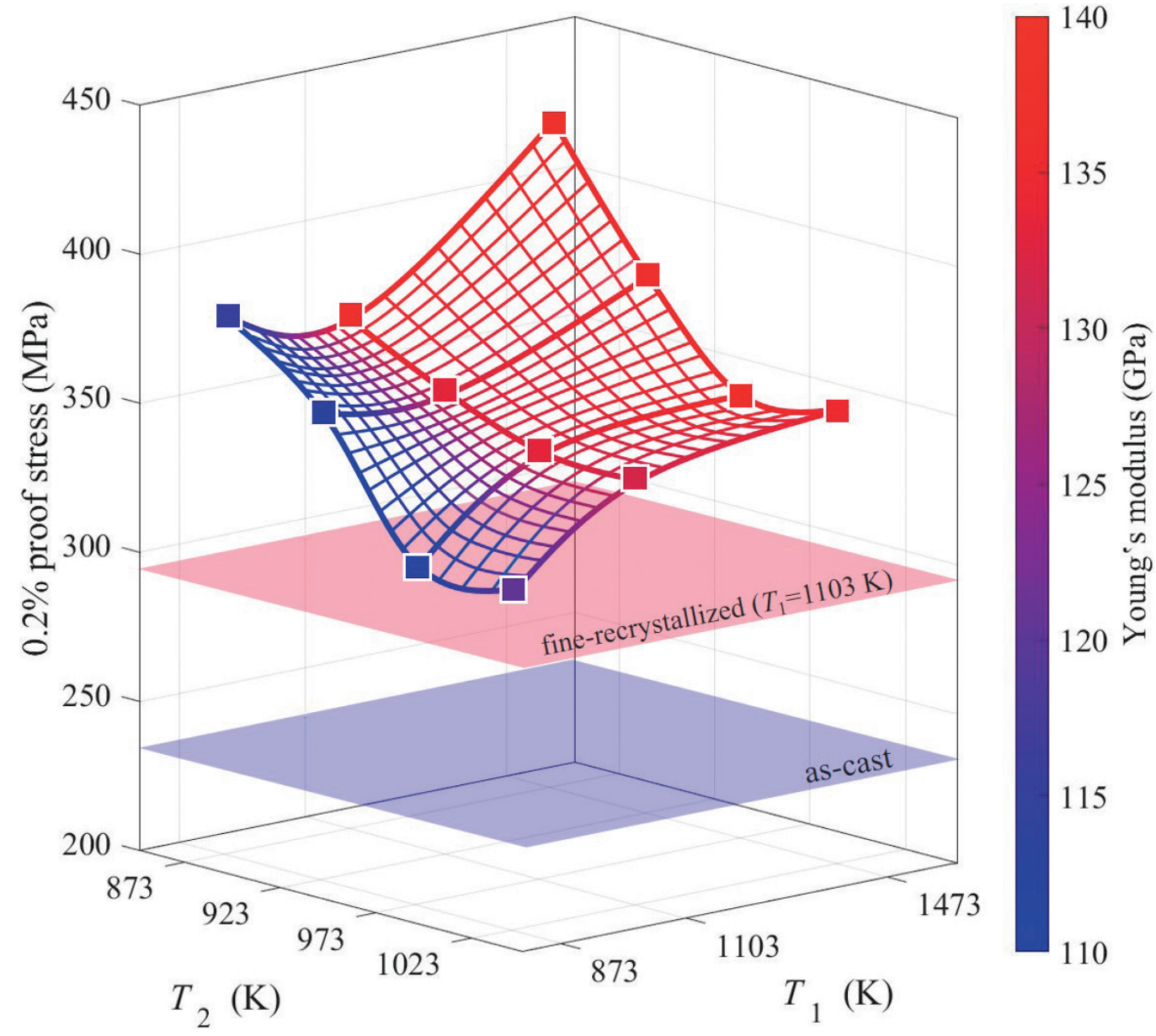

Fig. 8. Variations of Young's modulus and $0.2 \%$ proof stress as functions of annealing temperatures, $T_{1}$ and $T_{2}$, on double cryo-annealing process.

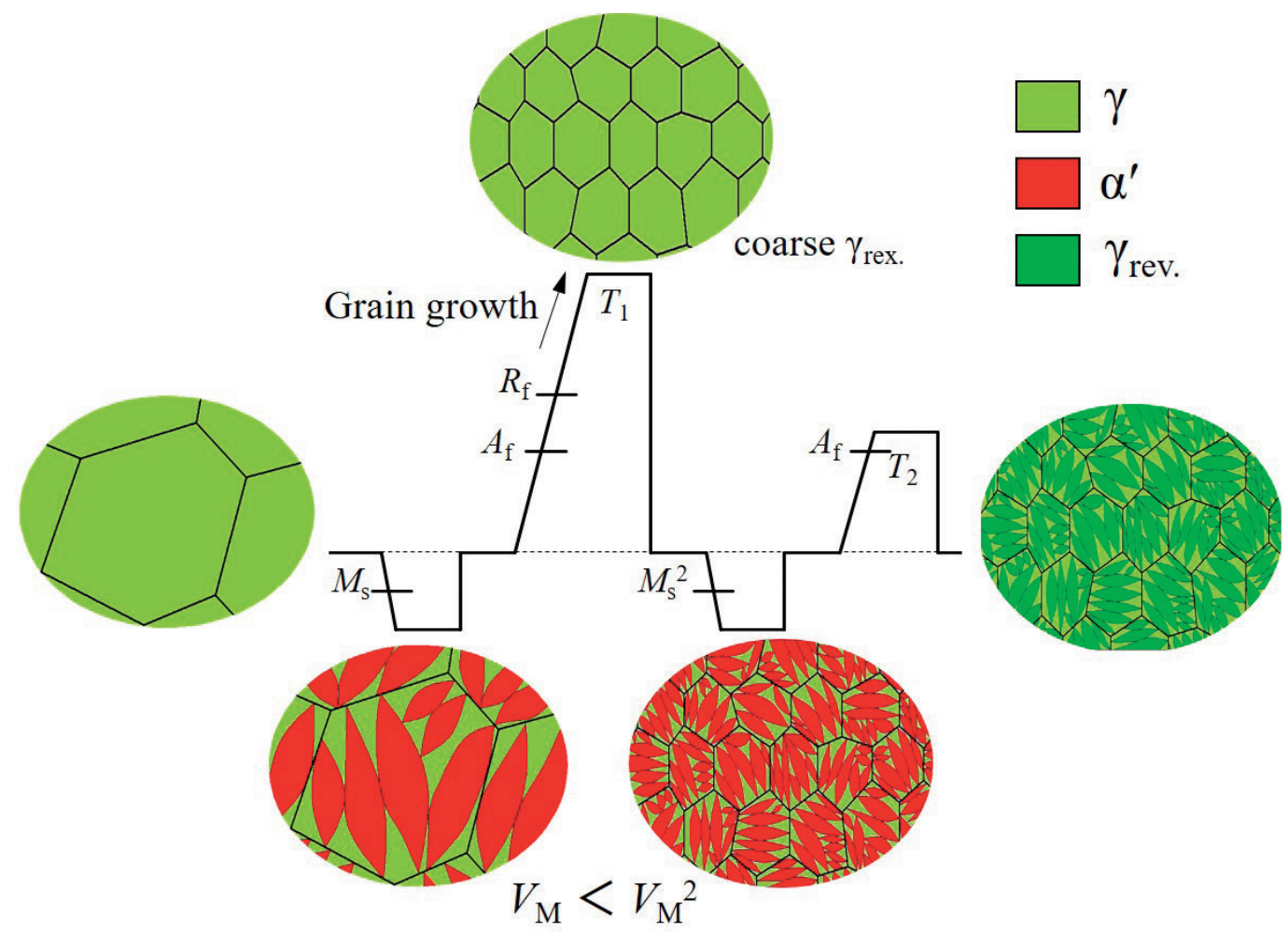

Fig. 10. Schematic illustration explaining appropriate heat treatment condition of double cryo-annealing process for simultaneous optimization of rigidity and strength. 
変化を調査した。得られた結論を以下にまとめる。

(1) クライオアニール処理における焼鈍温度が $A_{\mathrm{f}}$ 点直上の 低温である場合, 高密度の転位を有した逆変態オース ナイトが維持されるため, 強度は顕著に上昇するが, 可逆的な結晶方位の変化によって集合組織が継承され るためヤング率は改善されない。これに対して, 焼鈍 温度が高くなると, 逆変態オーステナイト中の転位を 駆動力として，オーステナイト再結晶が生じる。その 結果, 結晶方位がランダム化することでヤング率は改 善するが, 微細粒微細強化による強度上昇は小さく, 顕著な強度上昇は達成されない。

(2) サブゼロ処理によって生じるマルテンサイト変態開始 温度はオーステナイト結晶粒径の微細化によって連続 的に低下する。しかしながら，オーステナイト粒界は マルテンサイトの核生成サイトになると考えられ, 結 果として, オーステナイト粒径が適度に粗大な場合に マルテンサイト体積率は最大值を示す。

(3) ダブルクライオアニール処理後のヤング率は 1 回目の 焼鈍温度に, $0.2 \%$ 耐力は 2 回目の焼鈍温度に強く依存 する。そのため, ダブルクライオアニール処理におい て，1回目の焼鈍温度を意罒的に高くすることで，オー ステナイトの再結晶とその後の粒成長を促す。そし て, 2 度目のクライオアニール処理を逆変態終了温度 の直上に設定し, 高強度な逆変態オーステナイトを多 量に生成させることで，スーパーインバー鋳鋼の剛性 と強度を同時に改善することが可能となる。

\section{文献}

1 ) H.Masumoto, M.Kikuchi and S.Sawaya: J. Jpn. Inst. Met., 33(1969), 1299 (in Japanese). https://doi.org/10.2320/jinstmet1952.33.11_1299

2 ) N.Sakaguchi, K.Ona, R.Bao and N.Nakada: ISIJ Int., 60(2020), 2609. https://doi.org/10.2355/isijinternational.ISIJINT-2020-254

3 ) R.Bao, N.Sakaguchi and N.Nakada: Materialia, 15(2021), 100995. https://doi.org/10.1016/j.mtla.2020.100995

4 ) J.-J.Zheng, C.-S.Li, S.He, B.Cai and Y.-L.Song: Mater. Sci. Eng. A, 670(2016), 275. https://doi.org/10.1016/j.msea.2016.06.004

5 ) A.Vinogradov, S.Hashimoto and V.I.Kopylov: Mater. Sci. Eng. A, 355(2003), 277. https://doi.org/10.1016/S0921-5093(03)00082-0

6 ) K.Nakama: Ph. D. thesis, Kyoto University, (2014), (in Japanese). https://doi.org/10.14989/doctor.k18276

7 ) H.Liu, Z.Sun, G.Wang, X.Sun, J.Li, F.Xue, H.Peng and Y.Zhang: Mater. Sci. Eng. A, 654(2016), 107. https://doi.org/10.1016/j.msea. 2015.12.018

8 ) M.Tsuda: Tetsu-to-Hagané, 80(1994), 944 (in Japanese). https://doi. org/10.2355/tetsutohagane1955.80.12_944

9 ) G.Krauss: Sc, D. Thesis, Massachusetts Institue of Technology, (1961), http://hdl.handle.net/1721.1/11317, (accessed 2020-12-07).

10) B.Hyatt and G.Krauss: Trans. Am. Soc. Met., 61(1968), 168.

11) T.Maki, D.Nakagawa and I.Tamura: J. Jpn. Inst. Met., 44(1980), 1164 (in Japanese). https://doi.org/10.2320/jinstmet1952.44.10_1164

12) N.Nakada, S.Kawasaki, Y.Kogakura, T.Tsuchiyama and S.Takaki: Mater. Sci. Eng. A, 690(2017), 270. https://doi.org/10.1016/j.msea. 2017.03.002

13) Y.Imai, M.Izumiyama and S.Hanada: J. Jpn. Inst. Met., 31(1967), 898 (in Japanese). https://doi.org/10.2320/jinstmet1952.31.7 898

14) M.Umemoto and W.S.Owen: Metall. Trans., 5(1974), 2041. https:// doi.org/10.1007/BF02644497

15) K.Tsuzaki and T.Maki: Netsu Shori (J. Jpn. Soc. Heat Treat.), 32(1992), 10 (in Japanese).

16) N.K.Nagpaul and D.R.F.West: J. Iron Steel. Inst., 208(1970), 276.

17) G.Krauss, Jr. and M.Cohen: Trans. AIME, 224(1962) 1212.

18) A.Alaei, H.Jafarian and A.R.Eivani: Mater. Sci. Eng. A, 676(2016), 342. https://doi.org/10.1016/j.msea.2016.09.003 